http://dx.doi.org/10.12775/szhf.2015.055

SERGII IAgODZINSKYI

National Aviation University, Kiev, Ukraine

SOPHIST@NAU.EDU.UA

\title{
Global Consciousness as a Cultural and Historical Concept
}

In the time of global information networks, the pursuit of unity of the humankind has transformed into a major conceptual social project. State borders of the geopolitical West have conventionally outlined the spheres of influence due to successful implementation of a range of innovative solutions at the turn of the $21^{\text {st }}$ century. Intensification of integration processes in the realms of economics, culture, law, education, and warfare urged researches to coin the terms of global thinking, global consciousness, planetary personality, etc.

The conditions, which enabled the person to identify themselves with the entire humanity both in the civilizational and sociocultural dimensions, presented a non-biased frame for the respective social discourse. In the days of Socrates, Leonardo da Vinci, G. Galilei, J. J. Rousseau, G. Hegel, the idea of all-encompassing unity was of a contemplative nature and was not rooted into social facts. On the other hand, in the globalized world any developments can influence the security and stability of individuals, groups, or states. Nevertheless, mastering the innovational, and, correspondingly, sociocultural potential of the system of global information networks, the person can- 
not totally comprehend the correlation of their own activity and the changes in the social space.

It is hardly an exaggeration to label the understanding of functioning of responsibility, interference, and dependence mechanisms in the social system of the globalized society as superficial and labile on the level of social psychology. We are of the opinion that the lack of methodology in coordination of particular actions, social activity, and civilization consequences constitutes the main reason for social fallouts, revolutions, wars and international conflicts. That is why the analysis of the phenomenon of the global consciousness in the light of individual perception of planetary effects caused by social actions is a topical social and philosophical issue.

Within the outlined problem we will focus on the analysis of historical and philosophical origins of the global consciousness notion, and on its representation as a cultural and historical concept of the information society.

First and foremost, we will narrow down the notion of cultural and historical concept. In the present paper it is used in the context of social-constructivist school in philosophy and we understand it as a set of ideas, principles, theories, which can be accepted by society as normative and ensure the survival of the humankind. With the necessity of objectivation acknowledged, sociocultural constructs become ontologically equal to the structural components of the social reality. Morals, money, public authority, classes, ranks, titles, etc. belong to the constructs implemented into social space.

Each historical epoch generates new constructs and transforms the existing ones on the basis of its inherent cultural and civilization coordinates. Playing the role of socio-cultural factors, they provide the procedure for the legitimation of social institutions. Consequently, the information society also produces its constructs in an effort to embody the ideal social model in them.

However, the expediency of removing the concept of global consciousness on the level of cultural-historical construct remains unanswered. No less a debate among scientists is also the content and place specified construct with the implementation of the social potential of the information age.

There are several reasons for this scepticism in our opinion. Firstly, modern civilization challenges are so unpredictable and global, that an opinion about their solution by imposing the public consciousness another theoretical construct seems illusory. Secondly, the postmodern experience of over- 
coming narratives (which include social constructs) approved distrust and hindered their development and implementation. Thirdly, the ethical orientation of most cultural and historical structures reduces social trust to them in the conditions of intensification of the technologies for manipulating of public opinion.

With this in mind, the only way to attract the innovative, educational, cultural potential of some construct believes identifying its historical-cultural and cultural-civilization sources. Like any other form of development, social development is the combination of evolutionary and commercial components. At the same time, any internal combinations of events and their causes, the trajectory of development is logical. Therefore, each historically conditioned phenomenon in one form or another should be reflected in the following socio-cultural transformation of society.

Looking for conceptual analogues of construct of global consciousness, researchers have repeatedly appealed to the philosophical heritage of representatives of the Cosmic Philosophy (V. Vernadskiy, O. Chizhevskiy, M. Kholodniy, K. Tsiolkovskiy, M. Umov, V. Soloviev, P. Florensky, M. Bulgakov, S. Frank, P. de Charden and others). As a scientific-philosophical system, the Cosmic forms the idea of the wholeness of the universe and the relationship of Space with the processes of social life. According to the characteristic position of representatives of the Cosmic Philosophy, the universe is the house that mankind has to understand and master. Socio-philosophical and anthropological essence of cosmism can be expressed as follows: humanity is not only planetary phenomenon, but also of cosmic origin, and therefore in the future it will become a factor of change not only of the earth but also of the cosmic nature.

Following the aim of our study, we note that such views were typical of the ancient Greeks, after which they received the support of a number of religious thinkers of the Middle Ages, the Renaissance natural philosophers, representatives of the modern philosophy and non-classical science of the early twentieth century.

However, only the precursors of the space age had the first opportunity to implement these ideas in practice of social life. According to their vision the Universe had to prepare for its space destiny. Searching for the ways of such a transition made it possible to divide cosmism into three directions: the natural-scientific, religious and artistic. But the integrity of the study, the conceptual ideas were not affected and were presented in the way of public discourse about the future of planetary civilization. 
Although there are some concerns that in spite of the predictable ideas the Cosmic Philosophy did not receive the wide spread and remained a set of theoretical constructions, this article tries to focus on those aspects that are significant for the progress of humanity in the information age. Thus, at once it will be dissociated from the ecological, ethical, religious and futurist interpretation of social philosophical inheritance of cosmism. Developing these aspects (which quite often were just a passionate phantasmagoria), researchers move away from the main idea of this direction by adding to it absurd, contradictory, obviously incorrect guesses.

As an example, there's a quote from a typical scientific research, where the ideas of cosmism are originally regenerated: "Mankind needs a new Prophet, who'd manage to engage people to search the road to the future, but not the past, to touch their souls and put a fire in the hearts, directing the human energy to spiritual revival.... The gift of creation, which owns the man, originally divided the World on smaller entities eventually penetrated so deeply that stumbled on the 'spine' of generalization. A circle was locked, creation, as unique noumen... lays a way to the reunion with General." Obviously, such thoughts not only distort the perception of conclusions and predictions of cosmism but also serve as an occasion to put their work on the shelf of history.

For this reason, addressing the formation of cultural and historical concept of global consciousness to cosmists' art, there is a limitation among the opinions of representatives of this scientific direction. Only by defining the framework of the construction will it be possible to discover another aspects.

The largest heuristic potential in the context of this study belongs to the Ukrainian scientist, the first president of The National Academy of Sciences of Ukraine V. Vernadskiy. As well as other cosmists, he went out of the scientific knowledge existing in that time, considering that "in science there is no awareness that the phenomenon of life and the phenomenon of dead nature, taken from a geological, i.e. planetary perspective, are the manifestation of a single process"2. Thus, life is not a random phenomenon, but a natural result of the world evolution. Actively affecting the biosphere by science and innovation, Humanity turns it into the noosphere. Being explored by means of devices and mechanisms, the noosphere newly organizes the biosphere.

${ }^{1}$ E. Azroianz, Globalization: Accident or the path for development? Modern trends of global development and political ambitions, Moscow 2002, p. 296.

${ }^{2}$ V. Vernadskiy, Living substance, Moscow 1978, p. 12. 
The above-mentioned ideas were not the product of theorizing detached from the reality of thoughts. V. Vernadskiy proved that at some period of the history of Earth the mass of living matter had become so critical that it resulted in the appearance of thinking beings, the proportion of which was not great in the first stages. However, guided by their own mind, a human modified all surrounding matter and that's why the humanity became a significant geological power. Alongside with this, we started to understand that "the eternity of life in the Universe doesn't guarantee its eternity on our planet". Only by realizing the unity of a human and the Cosmos, attracting all intellectual capacity for preserving their harmonious development and mutual care can we find the way to guarantee the long-term existence of civilization and culture.

The course of history must transform social consciousness into global consciousness. In such a way the thinker has shifted the responsibility for further destiny of Earth, nature, humankind to every individual who once started transforming the biosphere is not able to stop, slow down or turn the process in the opposite direction. Thereupon the researcher makes the conclusion that the existence of factors independent from the environment is impossible ${ }^{4}$. Going further in his conclusions, he suggests that subsequently the Cosmos will become the environment of human livelihoods. On the level of social consciousness there had to be stated the priority of space exploration, searching new energy resources, innovative materials, health care improvement, targeting the technological breakthrough in the fields of science, education and technologies.

Other representatives of cosmic philosophy also justified the idea of the necessity of escaping from the planet scope. Thus, a Ukrainian biologist M. Kholodniy was inclined to the idea of space origin of human intellect. The convincing argument for "organic relationship of the mind with the whole universe is the effectiveness of mathematic analysis methods for accurate description, explanation and prediction or natural phenomena" ${ }^{5}$ that proves the mutual origin and co-evolution of human and the cosmos. Having taken the concept of "anthropocentrism" as a basis for his analysis, he eventually suggested to replace it by the concept of "anthropocosmism", the point of which is that the attitude of a human to the nature is currently changing,

\footnotetext{
${ }^{3}$ V. Vernadskiy, Living substance and biosphere, Moscow 1994, p. 120.

${ }^{4}$ V. Vernadskiy, About science. In 2 vol. V. 1. Scientific knowledge, Dubna 1997, p. 342.

${ }^{5}$ M. Kholodniy, Selected works, Kyiv 1982, p. 146.
} 
he endeavours not only to conquer it but also to comprehend the mysteries of the Cosmos and matter structure, and evolution.

The problem of the new concept expediency and its role in human social progress is appropriate in such a context. And though the ideas about connection of the Cosmos and humankind, suggested by M. Kholodniy, do not meet the status of instrumental knowledge, they bear conclusions which are important for the information age. Globalization, accelerated by information network, has given a human reasons to recognize themselves as a citizen of the world.

But this fact, in itself, does not impose on human the commitments for restructuring the relationship to themselves and to society. According to the idea of the Ukrainian explorer, the concept of the basic provisions antropocosmism should contribute to the development of new forms of public relations. As opposed to the scientist V. Vernadskiy, M. Kholodniy holds the each individual responsible for the future ${ }^{6}$. When analysing the key ideas of a natural-science direction of the Cosmic Philosophy it is impossible to ignore the scientific achievements of $\mathrm{K}$. Tsiolkovskiy. His achievements are still quoted in astrophysics, aerodynamics, and rocket building works. The famous scientist was one of the first to describe relationships between man and nature as the ratio of elements of a single system. Therefore, together with scientific findings ethical, religious, sociological, and futurist aspects have found place in his works. Comparative analysis of the human history has found an original cyclicity. Every consecutive circle of the cycle brings complications of the famous vital functions arrangement forms ${ }^{7}$. Such wave processes of coevolution allowed K. Tsiolkovskiy to form the concept of the Citizen of the Universe.

While his views on this concept can be called as metaphysical, it indicates the place of the man in Evolution of the Universe anyway. When the humanity has recognized the secrets, laws of miracles, beauty, the paradoxes and promises they have no rights to return to the previous era, and instead - they are obliged to enter a new era and be ready for a new trial and achievements.

On the basis of his scientific discoveries $\mathrm{K}$. Tsiolkovskiy built a coherent social utopia. With sincere hope for human desire for happiness, he proposed to develop the humanity consolidation projects actively and to search for an optimal model of administrative management, and also to involve nations

\footnotetext{
${ }^{6}$ M. Kholodniy, Selected works, Kyiv 1982, p. 178.

${ }^{7}$ K. Tsiolkovskiy, Cosmic Philosophy, Moscow 2001, p. 30-31.
} 
into universal foundations of moral discipline. In general, these social and philosophical ideas which were developed within the Cosmic Philosophy have both theirs supporters and critics alike. In any case there is an undeniable thesis that humanity cannot progress without having to overcome the baggage of contradictions which were accumulated by centuries. While achieving a high level of social self-organization, revealing the globalization potential, introducing a system of information networks we are convinced that humanity must be away from religious, ethical, aesthetic, legal, educational, and other types of the contradictions.

They should be like a decoration of nations and countries, but not their burden, the cause of conflict, death or suffering. Apparently, such changes require the evolution of social consciousness, to achieve the global level, which is indifferent to disagreements.

Such thoughts of scientists appear to express nothing more than their worldview orientation and cannot be verified by means of scientific facts, hypotheses, and theories. If it is true, then the conclusions cannot be the arguments neither in exact or natural sciences nor in humanities discussions.

In order to refute these accusations let's turn to the creative heritage of a prominent scientist, inventor and philosopher O. Chizhevskiy. By investigating solar activity, he proved its connection with civilization processes. Having studied the background of this problem, he found out that "a millennium before the beginning of the research study of nature, there was a deep conviction that the life was only the trembling of cosmic forces, the flow of cosmic energy"s. That is, the life of a human being and the vital activity of humanity are determined by cosmic processes among which one can observe the transition of cosmic energy to mental states. O. Chizhevskiy claimed that according to the cycles of solar activity weather conditions change as well as crop yield, animal migration, the activity of microorganisms, or the level of epidemiological diseases, frequency of sudden deaths etc. Thus, we cannot exclude the human personality from the general structure of nature, and tear it away from mechanics of the Universe. At the same time O. Chizhevskiy emphasized that this influence was not direct and obvious; it should be detected, developed, and extended.

Thus, the "Cosmic Philosophy" raises the problem of forming a human with the developed intelligence, high moral qualities and the culture of think-

${ }^{8}$ O. Chizhevskiy, Cosmic pulse of life: Earth under the sun. Helyotaraksia, Moscow 1995, p. 502. 
ing; the human who has not only to find out the secrets of the Space but also apply this knowledge for mastering it. But only the consolidated society can reach the new boundaries of social space; the society that has overcome internal conflicts, hostility and racial, religious and other forms of hatred. In other words, society must find sources and mechanisms for consciousness regeneration, providing it with planetary, global measurement.

The conclusions of the representatives of the Cosmic Philosophy correlate with modern natural-scientific theories and humanities works. So, V. Stiopin and L. Kuznetsova discovered "the coincidence of basic principles of cosmic philosophy and many fundamental ideas of modern scientific picture of the world and its worldview conclusions" . Comparing the Cosmic Philosophy with postnonclassical science, L. Drotianko notes that "thinkers of this school involved the terminology of modern science at the beginning of the 19th century" ${ }^{10}$. The laws of non-equilibrium thermodynamics, representing nonlinear, stochastic, co-operative and similar properties of open self-regulating systems finally convinced the researchers of the rightness of the worldview orientation (outlined by cosmists) on Space interpretation as a part of social space.

Therefore we agree with A. Bazaluk's opinion, who believes that "the basis of a future person's outlook should be laid on the awareness that his life is a life of the civilization, and the civilization activity will be wide scaled and productive to that extent at which each person realizes oneself in life"11. Consequently, modern scholars are unanimous in actuality of cosmic ideas to understand the historical, cultural, and civilizational progress of mankind.

\section{Conclusions}

All that was mentioned above allows us to make several conclusions which specify the purpose of our research. First of all, let's pay attention to the cosmists' thesis on the relationship between life and natural processes. Translating this into the systems language, we get the law of direct dependence of social actions for the whole social space at the condition of its globalization. Meanwhile the global information networks, which determine the current

\footnotetext{
${ }^{9} \mathrm{~V}$. Stiopin, Scientific picture of the world in the culture of technogenic civilization, Moscow 1994, p. 242.

${ }^{10}$ L. Drotianko, The phenomenon of fundamental and applied knowledge, Kyiv 2000, p. 185.

${ }^{11}$ O. Bazaluk, World existence: Modern model «Evolving matter», Philosophy and Cosmology 1 (1) 2009, p. 4.
} 
social metrics, are not able to lead humanity beyond a global scale. Thus, social space does not expand as the creators of the digital revolution dreamt of, but shrinks with every technological or social and humanitarian innovation. Secondly, the noosphere provided social space with the third dimension, by having extended it physically. To move in three directions - civilizational, cultural, and noospheric - mankind must aim at all forms of social consciousness on a global perspective. Therefore, the task of understanding the global consciousness as a cultural and historical concept is considered to be a relevant social and philosophical issue. By solving it, not only will humanity gradually get rid of the burdens of past conflicts but also outline prospects for further development, deploy a new horizon, fully understand their essence as a universe intelligence carrier.

\section{References}

Azroânc È. A., Globalizaciâ: katastrofa ili put' $k$ razvitiû? Sovremennye tendencii mirovogo razvitiâ i političeskie ambicii / È. A. Azroânc, Moskva 2002 (Azroianz E., Globalization: Accident or the path for development? Modern trends of global development and political ambitions, Moscow 2002).

Bazaluk O. A., Suŝsstvovanie mira: sovremennaâ model' "Ėvolûcioniruûŝâ̂materiâ»" / O. A. Bazaluk // Filosofiâ i kosmologiâ, 2009, s. 3-36. (Bazaluk O., World existence: Modern model «Evolving matter», 2009).

Vernadskij V. I., Živoe veŝestvo / V. I. Vernadskij, Moskva 1978 (Vernadskiy V., Living substance, Moscow 1978).

Vernadskij V. I., Živoe veŝestvo i biosfera / V. I. Vernadskij, Moskva 1994 (Vernadskiy V., Living substance and biosphere, Moscow 1994).

Vernadskij V. I., O nauke. V 2-h t. T. 1. Naučnoe znanie. Naučnoe tvorčestvo.Naučnaâ mysl' / V. I. Vernadskij, Dubna 1997 (Vernadskiy V., About science, in 2 vol., v. 1. Scientific knowledge, Dubna 1997).

Drotânko L. G., Fenomen fundamental'nogo i prikladnogo znannâ (Postnekla-sične doslidžennâ) / L. G. Drotânko, Kyiv 2000 (Drotianko L., The phenomenon of fundamental and applied knowledge, Kyiv 2000).

Stepin V. S., Kuznecova L. F., Naučnâ̂ kartina mira v kul'ture tehnogennojcivilizacii / / V. S. Stepin, L. F. Kuznecova, Moskva 1994 (Stiopin V., Scientific picture of the world in the culture of technogenic civilization, Moscow 1994).

Holodnyj N. G., Izbrannye trudy / N. G. Holodnyj / Pod red. K. M. Sytnika,Kyiv 1982 (Kholodniy M., Selected works, Kyiv 1982).

Ciolkovskij K. Ė., Kosmičeskaâ filosofiâ / K. Ė. Ciolkovskij, Moskva 2001 (Tsiolkovskiy K., Cosmic Philosophy, Moscow, 2001). 
Čiževskij A. L., Kosmičeskij pul's žizni: Zemlâ v ob"âtiâh Solnca. Geliotaraksiâ / / A. L. Čiževskij, Moskva 1995 (Chizhevskiy O., Cosmic pulse of life: Earth under the sun. Helyotaraksia, Moscow 1995).

\begin{abstract}
The article analyses the ideas of representatives of cosmic philosophy. Cultural, historical and civilizational character of the phenomenon of global consciousness is presented. It is proved that global consciousness is a part of social and cultural potential of global information networks and may indicate the prospects of mankind as a mind bearer.
\end{abstract}

Key words: globalization, global consciousness, cosmic, information society, cultural and historical concept 